\title{
Diet and Endothelial Function
}

\author{
ADA M CUEVAS ${ }^{1}$ and ALFREDO M GERMAIN ${ }^{2}$
}

${ }^{1}$ Departments of Nutrition, Diabetes and Metabolism and of ${ }^{2}$ Obstetrics and Gynecology, Faculty of Medicine, Catholic University of Chile, Santiago, Chile

\begin{abstract}
Endothelial dysfunction is one of the earliest events in atherogenesis. A consequence of endothelial damage is a lower availability of nitric oxide (NO), the most potent endogenous vasodilator. NO inhibits platelet aggregation, smooth muscle cell proliferation and adhesion of monocytes to endothelial cells. Endothelial dysfunction is present in patients with cardiovascular disease and/or coronary risk factors, such as hypertension, dyslipidemia, diabetes, smoking or hyperhomocysteinemia. At present, soluble markers and high resolution ultrasound of the brachial artery, have provided simple tools for the study of endothelial function and the effects of several interventions. It has been demonstrated that dietary factors may induce significant changes on vascular reactivity. Nutrients, such as fish oil, antioxidants, L-arginine, folic acid and soy protein have shown an improvement in endothelial function that can mediate, at least partially, the cardioprotective effects of these substances. Attention has been focused on dietary patterns in populations with lower prevalence of cardiovascular disease. There is some evidence suggesting that Mediterranean diet characterized by high consumption of vegetables, fish, olive oil and moderate wine consumption may have a positive effect on endothelial function. These results give us evidence on the significant role of diet on endothelial function and its impact on the pathogenesis of atherosclerosis.
\end{abstract}

Key words: Diet, endothelial function, nitric oxide, vascular reactivity.

Abbreviations: EDRF: endothelium-derived relaxing factor; EPA: eicosapentaenoic acid; LDL: low density lipoprotein; MUFA: monounsaturated; NO: nitric oxide; NOS: nitric oxide synthase; SERM: selective estrogen receptor modulators.

\section{INTRODUCTION}

The vascular endothelium plays an important role in a number of homeostatic functions including the regulation of blood flow, vascular tone and platelet aggregation. These functions are mediated by the synthesis and release of several substances, mainly nitric oxide (NO) or endothelium-derived relaxing factor (EDRF), the most potent endogenous vasodilator known to date $(1,2)$.

Endothelial dysfunction, that is, the disruption of these vasoregulatory functions, is considered one of the earliest events in the development of atherosclerosis. Cardiovascular risk factors, such as hypercholesterolemia, cigarette smoking, hypertension, diabetes mellitus and hyperhomocysteinemia are frequently associated with abnormalities in vascular function, characterized by an increased response to specific vasoconstrictor agents and a pronounced attenuation of endotheliumdependent vasorelaxation $(3,4)$.

The clinical characteristics of endothelial dysfunction are enhanced and maintained endothelial activation and impaired endothelium-dependent vasodilation. Endothelial activation is detected by increased plasma concentration of soluble adhesion molecules that are released into the plasma from the activated endothelium (5). 
Failure in endothelium-dependent vasodilation can be detected in coronary vessels by coronariography post infusion of acetylcholine to measure changes in coronary artery diameter and vessel flow. However, this method is invasive and timeconsuming. A non-invasive and reproducible method has been developed that measures the vasodilator response of the brachial artery after the infusion of agonists, such as serotonin or acetylcholine or, more commonly, in response to increased flow induced by reactive hyperemia (6).

Several pharmacological and nonpharmacological strategies have been demonstrated to improve endothelial function. Pharmacological interventions include inhibitors of 3-hydroxy-3methylglutaryl coenzyme A reductase (statins), calcium channel blockers, angiotensin-converting enzyme inhibitors, estrogens and angiotensin-II receptor antagonists (4). Non-pharmacological interventions, such as physical activity, smoking cessation and nutritional factors also play an important role. In recent years, fatty acids, antioxidants, L-arginine, folic acid and soy protein have been the most evaluated substances.

\section{Fatty acids}

Several studies have shown that the acute administration of a high-fat meal induces a transitory disruption of endothelial function. This effect has been observed with different types of fats, including saturated, monounsaturated (MUFA) and trans fatty acids (7). Vogel et al. evidenced that a high-fat meal (containing predominantly saturated and trans fatty acids) induced an acute decrease in flowmediated vasodilation that correlated with a postprandial elevation of triglyceride-rich lipoproteins in the plasma (8). Another study showed that a meal containing predominantly MUFA, also produces an impairment in endothelial function when compared to a carbohydrate-rich-meal (9). Similarly, it was observed that a meal rich in olive oil, produces the same decline in flow-mediated vasodilation as did a fast food meal (7).
The effect of chronic consumption of a high-fat diet on endothelial function has also been evaluated. One study showed that a Mediterranean-type MUFA diet administered during 28 days to healthy subjects, produces a decrease in plasma markers of endothelial activation, suggesting an improvement in endothelial function (10). Similarly, the chronic consumption of low-fat diets and Mediterranean-style diets improve endothelial function compared to a high-fat Western-type diet (11). However, these studies did not differentiate the benefit attributed to the high consumption of natural antioxidants, characteristic of Mediterranean-style diets, from the effect of fat on endothelial function. We evaluated the effects of two high-fat diets: MUFA and n-6 polyunsaturated fatty acids (PUFA), both of them exiguous in fruits and vegetables. They were administered to healthy males during three weeks. It was detected that both diets, independent of the type of fat, elicited a significant decline in flow-mediated vasodilation. This negative effect was reverted when the subjects added red wine (two glasses per day) or fruit and vegetables to their diets (12). These data suggest that high-fat diets induce endothelial dysfunction that can be counteracted with the consumption of natural antioxidants.

The effect of n-3 fatty acids on endothelial function has also been evaluated. In vitro studies suggest that n-3 fatty acids decrease the expression of adhesion molecules on endothelium and decrease leukocyte-endothelium interactions (13). In addition, in coronary artery strips, fish oil augments endothelium-dependent relaxation (14). Eicosapentaenoic acid (EPA) may induce this effect by increasing the production and release of nitric oxide by an activation of nitric oxide synthase (NOS) (15). Human studies have shown that supplementation with n-3 fatty acids improves endothelial function, providing an additional mechanism for the beneficial effects of these fatty acids in coronary heart disease (16). In contrast to other fatty acids, acute administration of fish oil did not induce a deleterious effect on endothelial 
function (7) and its long-term administration is consistently associated to improved endothelial function $(17,18)$.

In conclusion, with the exception of n-3 fatty acids, acute or chronic high- fat meals induce a negative effect on endothelial function. This function is improved by the simultaneous administration of natural antioxidants, such as red wine, fruits and vegetables. Results of studies with fish oil provide further support to the beneficial effects of these fatty acids on endothelial function and cardiovascular disease prevention.

\section{Antioxidants}

The oxidative modification of low density lipoprotein (LDL) has been implicated in the development of atherosclerosis. Dietary antioxidants protect LDL molecules against oxidation and limit experimental atherosclerosis (19-22). Abnormalities in endothelium-dependent vasodilation may in part result from the effects of oxidized LDL on nitric oxide release. Moreover, oxidized LDL is cytotoxic to endothelial cells and chemotactic for monocytes, leading to the accumulation of vascular inflammatory cells and free radicals and to the inactivation of nitric oxide $(23,24)$. Antioxidants reduce LDL oxidation; early animal studies suggested that the administration of these substances preserves endothelium-dependent vasorelaxation (25). Human studies also support a beneficial role of antioxidants on endothelial function $(18,26)$. It has been detected that vitamin $\mathrm{C}$, a water soluble antioxidant, vitamin $\mathrm{E}$ and probucol, lipid soluble antioxidants, produce beneficial effects on endothelial function by decreasing the down regulation of endothelial NOS expression (27). Moreover, the deleterious effects of postprandial hypertriglyceridemia on endothelial-dependent vasodilation can be counteracted by the simultaneous administration of antioxidants, mainly vitamins $\mathrm{C}$ and $\mathrm{E}(28,29)$. Flavonoids and other polyphenols contained in foods such as red wine, tea, onions, apples and others, also have antioxidant properties, and there is evidence that their intake is associated with reduced cardiovascular risk $(30,32)$. In vitro studies have shown that wine polyphenols exert vasorelaxing activities in rat and rabbit aortic rings and in human coronary arteries $(33,34)$. Plant polyphenols from other sources have shown a similar activity. Recently, we observed that moderate red wine consumption counteracts endothelial dysfunction induced by a high-fat, Westernstyle diet administered to healthy men (35). Similarly, another study suggested that short and long-term black tea consumption reverses endothelial dysfunction in patients with coronary heart disease (36).

Taken together, the results of most of the studies support a beneficial role of antioxidants, mainly vitamins $\mathrm{C}, \mathrm{E}$ and polyphenols on endothelium function. This effect seems to be directly related to a reduction in oxidative stress.

\section{L-arginine}

L-arginine is a semi-essential amino acid and the substrate for NOS in the production of nitric oxide (37). Animal studies have shown that supplementation with L-arginine improves endothelium-dependent dilation, decreases platelet aggregation and monocyte adhesion and reduces the development of atherosclerosis $(18,38)$. However, the results on human interventions are more controversial. Some studies detected that L-arginine induces an improvement on endothelium dependent vasodilation, while others report no change. In patients with coronary artery disease, most studies have shown that L-arginine administration improves both endotheliumdependent vasodilation and abnormal interactions of vascular cells, platelets and monocytes (39). Similarly, L-arginine administration exhibits consistent beneficial effects on patients with hypercholesterolemia or cigarette consumption, both of which are well known cardiovascular risk factors that induce endothelial dysfunction (39). However, the benefit is not clear in healthy subjects or patients with diabetes or hypertension. Endothelial dysfunction associated to both of the latter conditions does not seem to be related to NOS substrate deficiency (39), that could explain the lack of effect of L- 
arginine interventions. Our preliminary (unpublished) data indicate that L-arginine supplementation $(0.1 \mathrm{mg} / \mathrm{kg}$ by oral route) for 6 weeks in patients with known cardiovascular atherosclerotic disease presenting severe endothelial dysfunction, was associated to a significant improvement in endothelial function.

During the reproductive period, some patients presenting with miscarriage, fetal death, fetal growth restriction or preeclampsia exhibit placental lesions indicating atherosclerotic vascular disease (40). The evaluation of their endothelial function during the non-pregnant period detected the presence of endothelial dysfunction of unknown origin in about $30 \%$ of them (41). In those women, early L-arginine supplementation $(0.1 \mathrm{mg} / \mathrm{kg}$ by oral route) (from 10 weeks gestation until term) improved maternal endothelial function, decreased uterine vascular resistance indexes (suggesting an improvement in uteroplacental blood flow) and was associated to a lower frequency of pregnancy complications, and a higher rate of live births (41). Additional well-controlled studies are necessary to confirm our results.

\section{Folic acid}

Homocysteine is a sulfur-containing amino acid that is formed during methionine metabolism. Serum homocysteine concentrations are frequently elevated in the elderly, in individuals deficient in folic acid, cyanocobalamin (vitamin B12) or pyridoxal phosphate (vitamin B6), and in the presence of some enzyme abnormalities (42). It is now well established that mild to moderate elevations in serum homocysteine plasma levels are associated with an increased risk of cardiovascular disease (43). Homocysteine increases platelet aggregation and thrombosis through enhanced thromboxane synthesis and inactivation of anticoagulant substances (44). In addition, cellular and animal studies suggest that homocysteine reduces the bioavailibility of NO by increasing superoxide production, which inactivates NO (45). There is increasing evidence that folic acid could have a beneficial effect on vascular reactivity. Clinical studies have detected impaired endothelial function in subjects with hyperhomocysteinemia or healthy subjects after oral methionine load. Acute administration of folic acid can restore disrupted endothelial function in those subjects (46). Also, chronic supplementation has shown a positive effect (18). This benefit is probably mediated by the homocysteine lowering effect of folic acid and by other mechanisms such as antioxidant properties and a direct increase of NO production (47, 48).

\section{Soy protein}

Dietary soy protein has been shown to have several beneficial effects on cardiovascular health. Its best-documented effect consists of a reduction of cholesterol and triglyceride concentrations $(49,50)$. In addition, soy protein exhibits potent antioxidant properties (50). These effects have been attributed to soy bean compounds, named isoflavones, mainly genistein, which act as selective estrogen receptor modulators (SERM). These compounds bind more strongly to estrogen receptor $\beta$, present in bone and vascular tissue, and with less affinity, they bind to estrogen receptor $\alpha$ (51). In addition to the antioxidant and lipid lowering effect, in vitro studies had suggested that genistein relaxes rat arteries by a NO-dependent mechanism (52), thus suggesting that these isoflavones could have direct beneficial effect on endothelial function. Furthermore, genistein enhances the vasodilator response of atherosclerotic arteries to acetylcholine (53). In addition, genistein supplementation improves endothelial dysfunction induced by ovariectomy in rats (54). Consistently, we recently demonstrated that supplementation with soy protein to postmenopausal hypercholesterolemic women improves flow-mediated dilation, regardless of changes in plasma lipoproteins. We hypothesized that isoflavones are responsible for this beneficial effect (55).

In conclusion, endothelial function can be modulated by some dietary components. The challenge for the future is to address the physiological mechanism of these components, and formulate dietary 
recommendations for populations at risk of cardiovascular disease.

\section{ACKNOWLEDGMENTS}

We acknowledge MEGODUC, Obstetrics and Gynecology group of the Catholic University of Chile for providing access to perform the high resolution vascular ultrasound in the brachial artery using last generation ultrasound equipment.

\section{SUPPORTED BY}

A research and development grant from Laboratorio Gynopharm, Grupo Recalcine and Grant PUC-PBMEC (Molecular Basis of Chronic Diseases Program), Catholic University of Chile.

\section{REFERENCES}

1. MOMBOUlli JV, VANHOUTTE P (1999) Endothelial dysfunction: from physiology to therapy. J Mol Cell Cardiol 31: 61-74

2. PEARSON JD. (2002) Endothelial cell biology: Recent advances. XLV Reunión Anual de la Sociedad de Biología de Chile. Biol Res 35: R-19

3. DE CATERINA R (2000) Endothelial dysfunctions: common denominator in vascular disease. Curr Opin Lipidol 11: 9-23

4. IRRIBARRA V, GERMAIN AM, CUEVAS A, FAÚNDEZ L, VALDÉS G (2000) Disfunción endotelial como alteración primaria en las patologías vasculares. Rev Méd Chil 128: 659-670

5. DE CATERINA R, MASSARO M (1999) Effects of diet and dietary components on endothelial leukocyte adhesion molecules. Curr Atheroscler Rep 1(3): 188195.

6. CELERMAJER DS (1998) Testing endothelial function using ultrasound. J Cardiovasc Pharmacol 32 (Suppl 3): S29-S32

7. VOGEL RA (2000) The Mediterranean diet and endothelial function: Why some dietary fats may be healthy. Clevel Clin J Med 67(4): 232-236

8. VOGEL RA, CORRETTI MC, PLOTNICK GD (1997) Effect of a single high fat meal on endothelial function in healthy subjects. Am J Cardiol 79: 350-354

9. ONG PJL, DEAN TS, HAYWARD CS, DELLA MONICA PL, SANDERS TAB, COLLINS P (1999) Effect of fat and carbohydrate consumption on endothelial function. Lancet 354: 2134

10. PÉREZ-JIMÉNEZ F, CASTRO P, LÓPEZ-MIRANDA J, PAZ-ROJAS E, BLANCO A, LÓPEZ-SEGURA F, VELASCO F, MARÍN C, FUENTES F, ORDOVAS JM (1999) Circulating levels of endothelial function are modulated by dietary monounsaturated fat. Atherosclerosis 145: 351-358
11. FUENTES F, LÓPEZ-MIRANDA J, SÁNCHEZ E, SÁNCHEZ F, PÁEZ J, PAZ-ROJAS E, MARÍN C, GÓMEZ P, JIMÉNEZ-PÉREZ J, ORDOVAS JM, PÉREZJIMÉNEZ F (2001) Mediterranean and Low fat diets improve endothelial function in hypercholesterolemic men. Ann Intern Med 134: 1115-1119

12. LEIGHTON F, SAN MARTÍN A, CASTILlO O, POLLAK F, PÉREZ DD, STROBEL P, URQUIAGA I, URZÚA U, DIEZ MS, FONCEA R; CUEVAS A, GERMAIN A, ROZOWSKI J, MEZZANO D (2000) Red wine, white wine and diet, intervention study. Effect on cardiovascular risk factors. Proceedings XXV Congres Mondial de la Vigne et de Vin, Paris.

13. SALJEFLOT I, ARNESEN H, BRUDE IR, NENSETER MS, DREVON CA, HJERMANN I (1998) Effect of omega 3 fatty acids and/or antioxidants on endothelial cell markers. Eur J Clin Invest 28: 629-635

14. SHIMOKAWA H, VANHOUTTE PM (1989) Dietary w3 fatty acids and endothelium-dependent relaxations in porcine coronary arteries. Am J Physiol 256: H968-H973

15. OMURA M, KOBAYASHI S, MIZUKAMI Y, MOGAMI K, TODOROKI-IKEDA N, MIYAKE T, MATSUZAKI M (2001) Eicosapentaenoic acid induces $\mathrm{Ca} 2+-$-independent activation and translocation of endothelial nitric oxide synthase and endotheliumdependent vasorelaxation. FEBS Letters 487: 361-366

16. GOODFELLOW J, BELLAMY MF, RAMSEY MW, JONES CJ, LEWIS MJ (2000) Dietary supplementation with marine omega-3 fatty acids improves systemic large artery endothelial function in subjects with hypercholesterolemia. J Am Coll Cardiol 35 (2): 265270

17. JOHANSEN O, SELJFLOT I, HOSTMARK AT, ARNESEN H (1999) The effect of supplementation with omega-3 fatty acids on soluble markers of endothelial function in patients with coronary heart disease. Arterioscl Thromb Vasc Biol 19: 1681-1686

18. BROWN AA, HU FB (2001) Dietary modulation of endothelial function: implications for cardiovascular disease. Am J Clin Nutr 73: 673-686

19. BERLINER JA, HEINECKE JW (1996) The role of oxidized lipoproteins in atherosclerosis. Free Radic Biol. Med 20: 707-727

20. DÍAZ MN, FREI B, VITA JA, KEANEY JF (1997) Antioxidants and atherosclerotic heart disease. N Engl J Med 337: 408-416

21. NAITO Y, SHIMOZAWA M, MANABE H, KURODA M, TOMATSURI N, UCHIYAMA K, TAKAGI T, YOSHIDA N, YOSHIKAWA T (2004) Inhibitory Effects of Red Wine Extracts on EndothelialDependent Adhesive Interactions with Monocytes Induced by Oxysterols. Biol Res 37: 231-238

22. LAMUELA-RAVENTÓS RM, GIMENO E, FITÓ M, CASTELlOTE AI, COVAS M, DE LA TORREBORONAT MC, LÓPEZ-SABATER MC (2004) Interaction of Olive Oil Phenol Antioxidant Components with Low-density Lipoproteins. Biol Res 37: 247-252

23. CARR AC, ZHU BEN-ZHAN, FREI B (2000) Potential antiatherogenic mechanisms of ascorbate (vitamin C) and $\alpha$-tocopherol (vitamin E). Cir Res 87: 349-354

24. CHIN JH, AZHAR S, HOFFMAN BB (1992) Inactivation of endothelial derived relaxing factor by oxidized lipoproteins. J Clin Invest 89: 10-18

25. STEWART-LEE AL, FORSTER LA, NOUROOZZADH J, FERNS GA, ANGGARD EE (1994) Vitamin E protects against impairment of endothelium-mediated relaxations in cholesterol-fed rabbits. Arterioscler Thromb 14: 494-499 
26. GUZMÁN P, MONTECINOS VP, ESCOBAR E, VERA JC. (2003) Role of glutatione and vitamin C against oxidative stress in human endothelial cells. XXVI Reunión Anual de la Sociedad de Bioquímica y Biología Molecular de Chile. Bio Res 36: R-153

27. RODRÍGUEZ JA, GRAU A, EGUINOA E, NESPEREIRA B, PÉREZ-ILZARBE M, ARIAS R, BELZUNCE MS, PARAMO JA, MARTÍNEZ-CARO D (2002) Dietary supplementation with vitamins $C$ and E prevents downregulation of endothelial NOS expression in hypercholesterolemia in vivo and in vitro. Atherosclerosis 165: 33-40

28. BAE JH, BASSENGE E, KIM KB, KIM YN, KIM KS, LEE HJ, MOON KC, LEE PARK KY, SCHWEMMER M (2001) Postprandial hypertriglyceridemia impairs endothelial function by enhanced oxidant stress. Atherosclerosis 155(2): 517-523

29. PLOTNICK GD, CORRETTI MC, VOGEL RA (1997) Effect of antioxidant vitamins on the transient impairment of endothelium-dependent brachial artery vasoactivity following single high fat meal. JAMA 278: 1682-1686

30. URQUIAGA I, LEIGHTON F. (2000) Plant polyphenol antioxidants and oxidative stress. Biol Res 33: 55-64

31. ARANEDA OF, BEHN C. (2002) Antioxidant Capacity and total Flavonoid content in Autoctonal Medicinals plants of Chile. XLV reunión Anual de la Sociedad de Biología de Chile. Biol Res 35: R-85

32. AVELLO M, PASTENE E, LAMPERTI L, DE DIEGO M, AHUMADA F, ULlOA N, SILVA V. (2002) Phytochemistry and biological activity of Ugni molinae Turcz ("Murtilla"). XLV Reunión Anual de la Sociedad de Biología de Chile. Biol Res 35: R-75

33. FLESCH M, SCHWARZ A, BOHM M (1998) Effects of red and white wine on endothelium-dependent vasorelaxation of rat aorta and human coronary arteries. Am J Physiol 275: H1183-H1190

34. AMBRIAMBELOSON E, KLESCHYOV AL, MULLER B, BERETZ A, STOCLET JC, ANDRIANSITOHAINA R (1997) Nitric oxide production and endothelium-dependent vasorelaxation induced by wine polyphenols in rat aorta. Brit J Pharmacol 120: 1053-1058

35. CUEVAS AM, GUASCH V, CASTILLO O, IRRIBARRA V, MIZON C, SAN MARTÍN A, GERMAIN AM, LEIGHTON F (2000) A high fat diet induces and red wine counteracts endothelial dysfunction in human volunteers. Lipids 35: 143-148

36. DUFFY SJ, KEANEY JF, HOLBROOK M, GOKCE N, SWERDLOFF PL, FREI B, VITA JA (2001) Shortand long term black tea consumption reverses endothelial dysfunction in patients with coronary heart disease. Circulation 104: 151-156

37. GUOYAO W, MORRIS SM (1998) Arginine metabolism: nitric oxide and beyond. Biochem J 336: $1-17$

38. ADAMS MR, McCREDIE R, JESSUP W, ROBINSON J, SULLIVAN D, CELERMAJER DS (1997) Oral Larginine improves endothelium-dependent dilatation and reduces monocyte adhesion to endothelial cells in young men with coronary artery disease. Atherosclerosis 129: 261-269

39. GOUMAS G, TENLOLOURIS C, TOUSOULIS D, STEFANADIS C, TOUTOUZAS P (2001) Therapeutic modification of the arginine-eNOS pathway in cardiovascular disease. Atherosclerosis 154: 255-267

40. CASANELLO P, SOBREVIA L. (2002) Chronic Hypoxia and intrauterine growth retardation, two models of endotelial dysfunction associated with lower activity of 1 -arginine/nitric oxide pathway in human fetal endothelium. XLV Reunión Anual de la Sociedad de Biología de Chile. Biol Res 35: R-18

41. GERMAIN AM, IRRIBARRA V, FAÚNDEZ L, VALDES G (2001) ¿Puede prevenirse la preeclampsia a través del reconocimiento de la disfunción endotelial primaria y de su manejo con L-Arginina? ¿Cómo ayuda el ultrasonido Doppler? Rev Chil Ultrasonog 4 (3): 72-78

42. UBBINK JB, VERMAAC WJH, VAN DER MERWE A, BECKER PJ (1992) Vitamin B12, vitamin B6 and folate nutritional status in men with hyperhomocysteinemia. Am J Clin Nutr 55: 1154-1160

43. HANKEY GJ, EIKELBOM JW (1999) Homocysteine and vascular disease. Lancet 354: 407-413

44. HAYNES WG (1999) Vascular effects of homocysteine: therapeutic implications. Heart Failure 15: $153-163$

45. STAMLER JS, OSBORN JA, JARAJI O, RABBANI LE, MULLINS M, SINGEL D, LOSCALZO J (1993) Adverse effects of homocysteine are modulated by endothelium-derived relaxing factor and related oxides of nitrogen. J Clin Invest 91: 308-318

46. USUI M, MATSUOKA H, MIYAZAKI H, UEDA S, OKUDA S, IMAIZUMI T (1999) Endothelial dysfunction by acute hyperhomocysteinemia: restoration by folic acid. Clin Sci 96: 235-239

47. DOSHI SN, McDOWELL IF, MOAT SJ, LANG D, NEWCOMBE RG, KREDAN MB, LEWIS MJ, GOODFELLOW J (2001) Folate improves endothelial function in coronary artery disease: an effect mediated by reduction of intracellular superoxide? Arterioscler Thromb Vasc Biol. 21(7): 1196-1202

48. STROES ES, VAN FAASSEN EE, YO M, et al. (2000) Folic acid reverts dysfunction of endothelial nitric oxide synthase. Circ Res 86: 1129-1134

49. ANDERSON JW, JOHNSTONE BM, COOK-NEWLL ME (1995) Meta-analysis of the effects of soy protein intake on serum lipids. N Engl J Med 333: 276-282

50. LICHTENSTEIN AH (1998) Soy protein, isoflavones and cardiovascular disease risk. J Nutr 128: $1589-1592$

51. MAKELA S, SAVOLAINEN H, AAVIK E, MYLLARNIEMI M, STRAUSS L, TASKINEN E, et al. (1999) Differentiation between vasculoprotective and uteroprotective effects of ligands with different affinities to estrogen receptors $\alpha$ and $\beta$. Proc Natl Acad Sci USA 96: 7077-7082

52. SQUADRITO F, ALTAVILLA D, MORABITO N, CRISAFULLI A, D'ANNA R, CORRADO F, RUGGERI P, CAMPO GM, CALAPAI G, CAPUTI AP, SQUADRITO G (2002) The effect of the phytoestrogen genistein on plasma nitric oxide concentrations, endothelin-1 levels and endothelium dependent vasodilation in postmenopausal women. Atherosclerosis 163: 339-347

53. HONORE EK, WILLIAMS JK, ANTHONY MS, CLARKSON TB (1997) Soy isoflavones enhance vascular reactivity in atherosclerotic female macaques. Fertility Sterility 67: 148-54

54. SQUADRITO F, ALTAVILLA D, SQUADRITO G, SAITTA A, CUCINOTTA D, MINUTOLI L, DEODATO B, FERLITO M, CAMPO GM, BOVA A, CAPUTI AP (2000) Genistein supplementation and estrogen replacement therapy improve endothelial dysfunction induced by ovariectomy in rats. Cardiovasc Res 45: 454-462

55. CUEVAS AM, IRRIBARRA VL, CASTILLO OA, YÁÑEZ MD, GERMAIN AM (2003) Isolated soy protein improves endothelial function in postmenopausal hypercholesterolemic women. Eur J Clin Nutr 57: 889-894 